\title{
Aprender a aprender (Lecturas literarias de un editor)
}

\author{
MANUEL BORRÁS
}

Editorial Pre-Textos

España

Las cosas, por fortuna, han cambiado para bien. De la época no tan lejana en que la máxima "La letra con sangre entra" era moneda corriente, y casi diría que una constante entre una burguesía emergente e iletrada, a los tiempos actuales, las cosas han variado ostensiblemente para mejor. De considerar la lectura como un lujo simplemente ocioso a asumirla como un elemento de prestigio social se ha avanzado un paso de gigante. Con todo, todavía falta mucho para que nuestro país pueda considerarse un país de lectores estables, y más en un momento histórico en que está haciéndose todo lo posible, como vaticina Alberto Manguel, para acabar con el mundo intelectual.

El amor a la lectura es algo que se aprende, que no puede enseñarse. De la misma forma que nadie puede obligarnos a enamorarnos, nadie puede obligarnos a amar un libro. Son cosas que ocurren por razones misteriosas, y por eso a todos nos espera un libro. En algún lugar de la biblioteca universal hay una página escrita para nosotros.

Trataré, en principio, de definir qué es para mí la lectura. Qué supone para un editor literario como yo el hecho de leer. Y estableceré una distinción entre lectura privada y lectura profesional.

Para mí leer supuso desde muy pronto un modo de estar en el mundo, un claro acicate para paliar mi soledad. Sí, fui un niño solitario que crecí entre libros y gocé de una familia y una casa donde había una biblioteca. Algo tan elemental, pero a la vez tan difícil en una España bastante oscurantista y en la que el segmento social al que yo pertenecía era, si no impermeable a la literatura escrita, sí remiso a considerarla como 
un bien indiscutible. No olvidemos que en tiempos de mi infancia todavía se tenía a la persona culta por sospechosa, como alguien que no se plegaba a las directrices dictadas por aquellos que decían haber ganado una guerra.

Aunque no disponía de mucho tiempo libre, debido al muy estricto programa de estudios al que estaba sometido en el colegio en que me eduqué, una vez inoculado el gusanillo de la lectura, siempre conseguí un rato, las tardes, durante los trayectos del autobús escolar, en alguna ocasión una jornada entera, en que podía disfrutar de mi soledad sin tener que atender las tareas escolares; siempre conseguí, decía, el tiempo para encontrarme con la quietud y el silencio suficientes a fin de sentir pasar las horas y observar las cambiantes luces del día reflejadas sobre las páginas de un libro, en ese estado de languidez, y aún de dulce aburrimiento, que es el clima de la lectura prolongada. Nunca me cansaba de leer. Me temo mucho que los jóvenes de hoy, demasiado distraídos por lo visual, algo que no debería ser incompatible con la lectura, no se detienen para paladear ese ocio creador e iluminador.

La lectura ha sido para mí motivo de alegría y, en algunos desdichados momentos de mi vida, al término de la infancia, tal vez una de mis más profundas satisfacciones. Los libros acompañaron mi difícil transitar de la pubertad a la adolescencia, de la adolescencia a la juventud, cumpliendo casi el papel de una terapia; me ofrecieron modelos con que fui conformando mi carácter y temperamento, forjando en suma mi personalidad. A través de la lectura adquirí conciencia de mí mismo y del mundo, multiplicando hasta el infinito las experiencias; disfruté de aventuras insólitas, de viajes a países exóticos que todavía no he visitado y, como en la máquina del tiempo, regresé a épocas pasadas. Conocí a seres que jamás se hubieran cruzado en mi camino, me asomé a la variedad de culturas y costumbres del vasto universo, familiarizándome con lo desconocido, con lo extraño, con lo diferente. Me liberé para siempre del oscurantismo que imperaba en nuestro país durante mi infancia y primera juventud, del etnocentrismo, de la xenofobia. Escapé de la insoportable estrechez del lugar que me había sido asignado y rompí con los límites de mi contingencia.

Leer es un modo de incorporarse al mundo, de establecer puentes con aquello que no conocemos y está esperándonos. Con eso que nos aguarda fuera y que si a la postre ignoramos sin duda supondrá una pérdida cualitativa en lo que a nuestra 
evolución sutil, a nuestro crecimiento como personas, en el sentido griego de la palabra, respecta.

Las carencias en la lectura comienzan con lo que denominamos "educación literaria". Por muchos procedimientos persuasivos o coercitivos que se empleen, "el caballo no bebe si no tiene sed". Sentencia esta que se completa muy bien con los versos de Isabel Escudero:
Un burro de noria
Fue mi maestro,
Por más agua que saco
De sed me muero.

No os forjéis ilusiones: no escribo para descubrir fórmulas mágicas con el fin de conseguir hacer lectores. No existen leyes para eso. Siempre intento concienciar a la gente de que nada verdaderamente importante en la vida requiere urgencia, de que leer se trata de un proceso muy largo y gozoso, que no hay que cejar en él, que hay que poner al alcance de cada persona lo que se "sospecha" que va a moverle a emociones, intereses, curiosidades... y después esperar. Vivimos demasiado sometidos a la dictadura de la velocidad, lo cual es letal para la lectura.

A leer se empieza por el oído, y oímos ya en el seno materno. En la infancia, la base de todo está en el folclore y la tradición oral. Todavía repican en mí, como recordaba hace poco en un programa de radio, las nanas que me cantaban de niño. Y siempre que tengo que escribir sobre mi formación intelectual digo que mi actual condición de lector gustoso se la debo principalmente a dos mujeres: a mi madre, que me leía desde muy pequeño y me animó a asomarme a la biblioteca familiar, y a una cocinera extremeña, llamada Eugenia, que contaba como nadie los cuentos.

En fin, que el amor a la lectura, como nos recuerda Gianni Rodari, no es una técnica, sino algo mucho más profundo, vinculado a la vida. La vida va más allá de lo que nuestra razón alcanza. Leer es una manera de atender a esa vida más profunda en constante y firme crecimiento y transformación. La literatura, sea oral o escrita, supone siempre una puerta que se abre paralelamente al mundo exterior e interior del lector. 
El niño, por naturaleza, desea aprender y necesita historias que le hablen de ese mundo donde lo cotidiano y lo prodigioso se dan la mano.

Nuestra dignidad no se halla en lo que hacemos, sino en lo que comprendemos. El niño no es sagrado por lo que es, sino por el hombre que será. La materia prima del arte es la vida. Si no comprendemos ese principio, no comprenderemos nada. El arte, la literatura debe responder a lo que es la vida tal cual ella es en realidad. La función del arte es, en suma, mejorar la existencia. No es tarea específica del artista descubrir en profundidad que la experiencia corriente está sumida en conflictos y confusiones; la tarea que le compete, hasta cierto punto, es la de sacar a flote la experiencia de la vida, ni más ni menos.

¿Cómo podemos animar a la lectura? Desde hace tiempo, la expresión "animación a la lectura" ha ido acuñándose y cobrando cada vez más fuerza en el ámbito educativo y cultural. Sin embargo, y con demasiada frecuencia, da la impresión de que con esta fórmula se designa un concepto que no se corresponde con las palabras que lo nombran.

“Animación" procede de anima, palabra latina que significa aire, aliento, alma. Por consiguiente, por "animación a la lectura" deberíamos entender la acción de airear, de dar un aliento de vida al texto, que conduzca al receptor a descubrir y gozar del alma de la lectura.

En el tema que nos ocupa, el orden de los factores sí altera el producto, y mucho. Si la supuesta animación se ejerce con la intención previa, o incluso única, de instruir, de inducir al consumo de libros porque sí, de extraer de la lectura aprendizajes preconcebidos y moralejas o de convertirla en un mero espectáculo de entretenimiento "guay", el proceso se está planteando exactamente al revés de lo que "animación" significa desde su más pura acepción etimológica. De este modo resultará casi un imposible llegar a acceder al alma de la lectura, pues en el proceso ésta ya habrá quedado invalidada.

Dar alma a la lectura supone, ante todo, favorecer la puesta en marcha de las emociones, los afectos, las reflexiones, los descubrimientos y las satisfacciones que a cada receptor puede provocarle el hecho de leer. Se trata de un fluido que nos conduce alternativamente de lo particular a lo universal, y viceversa. 
El fomento de la lectura no se basa en otra cosa que en el contagio de la emoción y el placer por la misma. Ahora bien, una vez prendida la alarma de la lectura, ésta sí puede alimentar cualquier propuesta de recreación que nos conduzca a nuevos descubrimientos sobre el cuerpo de los textos, su anatomía, sus ritmos... y de nuevo su alma.

Pretender mediante instrucciones, repito, convertir a alguien en lector equivaldría a tratar de instruirle para que aprendiera a enamorarse. Como advertía Galileo: "No se puede enseñar nada a una persona, sólo se la puede ayudar a encontrar la respuesta dentro de sí misma". Ésa es la respuesta que he buscado tanto en mi tarea de lector personal como profesional. Si decidí ser editor lo hice en buena medida porque pensé que si la lectura me había ayudado a vivir, a ser mejor, ¿por qué no habría de reportar a los demás los mismos beneficios? Mi labor de editor me ha acercado a los otros, a aquellos incluso que nunca hubiera soñado conocer, y eso, no os quepa la menor duda, me ha ayudado mucho. La proximidad de los demás es una fuente de beneficios.

Me gustaría lanzar unas preguntas al aire: ¿Qué es aprender? ¿Cuántas veces nos hemos planteado esa cuestión? ¿Qué significado ha tenido ese verbo en nuestras respectivas vidas? En mi caso, aprender ha requerido siempre de una disposición de ánimo y de una atención muy precisa. Resulta un lugar común opinar que para aprender, en el sentido de aprehender -con hache-, hay necesariamente que prestar atención. Pero ¿qué supone en el fondo prestar atención para aprender a aprender? Significa sabernos dotados de libertad para oír y tener, ni más ni menos, los sentidos prestos a fin de recibir del exterior, del mundo, de la vida, aquellas señales que puedan, tras la reflexión adecuada y la, digamos, digestión de las mismas, reportarnos una enseñanza. Toda enseñanza, por pequeña que sea, es siempre resultado de la observación atenta, y añadiría que meticulosa, de la realidad que acontece en nosotros y a nuestro lado. Hay que arriesgarse, se necesita valor para aprender. Sólo se equivoca quien arriesga y para vivir en consecuencia, no ajenos a lo que acontece fuera de nosotros, hay que arriesgar, no temer equivocarse.

A veces cuando nos creemos imbuidos de una certeza (y de ahí que me refiera al valor que precisa querer aprender), adviene de pronto el efecto rectificador de la realidad para señalarnos lo equivocados que habíamos estado hasta el momento, lo 
ajenos que permanecimos respecto a la verdad, aunque paradójicamente nos hubiéramos creído poseedores de ella.

Leer es también salir de uno mismo para volver distinto, diferente tras haberse sometido a la intemperie de los otros, de nuestros vecinos, pero también de los interlocutores que al fin y al cabo son los personajes, por poner un ejemplo, de una novela, o de los diálogos que nos brindan los filósofos, de la reflexión y la mirada interior a la que nos animan los poetas, del conocimiento, en suma, que nos dan tanto las lecturas literarias como las puramente científicas.

Aun a riesgo de aburrir, insistiré una vez más en que siempre he sostenido que el editor literario antes que nada es un lector apasionado, un degustador, a ser posible, de la mejor literatura. Y también que el mejor libro que podemos escribir los editores es nuestro propio catálogo. Libro polifónico donde los haya, en que el editor ha de tratar de armonizar todo, para que no haya voces que desnaturalicen el tono general del mismo. Es decir, que un catálogo de una editorial literaria de verdad jamás puede ser un cajón de sastre, sometido al péndulo de las modas en curso ni de las distintas tribus estéticas que se mueven en un ámbito cultural concreto. Si el editor consigue ese objetivo su trabajo no sólo ganará en personalidad, sino también se singularizará en una época en que el seguidismo y el acuchillamiento de la ética parecen ser ya moneda corriente entre nuestra inteligencia.

Por contraste con la sociedad seguidista, gregaria y cada vez más conformista en la que vivimos, y en la que preferimos que se nos dé todo hecho antes que esforzarnos por la conquista de la libertad que afiance nuestra capacidad de elección individual, sólo unos pocos podemos, por desgracia, permitirnos el "lujo" de seguir creyendo y siendo exigentes con aquello que más estimamos. Sólo unos pocos, por lo que se ve, estamos en disposición de luchar contra la tiranía tanto del mal gusto, cuanto de la falta de gusto por las cosas que más apreciamos, como es en nuestro caso la literatura. Sólo unos pocos, por desgracia, nos hallamos en condiciones de expresar la alegría que supone poder aplicar un criterio personal, capaz de seleccionar, discernir y favorecer valores por los que la existencia valga la pena vivirse aun a costa de poner nuestros yos en crisis. El miedo -eso que nos expone más al peligro- a la posibilidad de equivocarnos suele ser una de las expresiones del miedo a la libertad. En nuestra época nadie parece querer resignarse al principio rectificador que impone la realidad. 
Estamos asistiendo, en fin, al fracaso de lo personal. Y nada apunta, pese a los cantos de sirena de un pretendido liberalismo edulcorado, a frenar en nuestros días la tendencia a la producción en masa, a las imitaciones vulgares y baratas, a la proliferación de los falsos valores, al conformismo, a la inflexibilidad, síntomas todos de una época estéril que pretende verse reflejada en lo contrario y cuya contundencia en su resistencia a desaparecer no es otra que la propia de una cultura que está dando sus últimos coletazos. Nos encontramos sumergidos en un momento en que cualquier idea original o su expresión libre y sin prejuicio es rápidamente deformada, oscurecida y arrumbada al anonimato, cumpliendo con esa terrible verdad de que ningún desconocido es echado de menos; inmersos, como estamos, en la confusión rampante entre calidad y cantidad.

El editor debería tratar cada vez más y con mayor ahínco de publicar aquello que no logra olvidar. Y aquello que no logra olvidar le impele a compartirlo con los otros. Es decir, el lector-editor es en el fondo aquel que no acaba de acostumbrarse a celebrar en solitario el milagro del día a día, de seguir vivos. De ahí también que necesite asomarse a los otros para festejar que no está solo. Nadie está radicalmente solo. Quizás ésta sea una de las revelaciones íntimas que haga a la literatura más necesaria para los hombres. Esa empresa, esa estrategia de supervivencia, pergeñada por el ser humano para tratar de explicarse el mundo, debe, aun siendo un producto intelectual, discurrir en paralelo a la vida. De hecho, a mi juicio, no hay literatura enajenada de la existencia. El que ve, tanto en la literatura como en la vida, siente el ver. El que escucha, siente el escuchar; el que camina, como nos señaló Aristóteles, siente el caminar. Y lo mismo vale para todas las demás actividades humanas, de tal modo que cada cual sienta que estamos ejercitándolas. O lo que es igual, que si sentimos, sintamos sentir; y si pensamos, nos sintamos pensar en plenitud. Y esto es lo mismo que sentirse existir. Existir, en efecto, significa sentir y pensar. La literatura siente lo que piensa y piensa lo que siente. Sentir que vivimos, viene a decirnos de nuevo Aristóteles, es por sí dulce, ya que la vida es por naturaleza un bien y es dulce sentir que un bien tal nos pertenece.

Vivir es deseable, sobre todo para quienes todavía creen que en cultura existe un horizonte ético, sean cuales sean sus circunstancias, ya que para ellos existir comporta un bien y una cosa dulce. Hay que tener el valor suficiente para probar la dulzura por el bien en sí. Para eso es necesario aprender a desprenderse de los prejuicios, de las ideas 
preconcebidas, y saber también ser en el fondo de nosotros mismos libres. Libres, ante todo, de todas las supercherías que condicionan nuestra época. Y lo que el hombre ético, el hombre bueno, prueba con respecto a sí, también lo prueba con respecto al amigo.

El amigo es en efecto un otro de sí mismo, aquel que nos protege de nosotros mismos. Por eso el editor siempre está remitiéndose al otro, en unos casos al autor, en otros al lector, ese que en su fuero interno es un crítico honesto. Y con ambos debe establecer un vínculo de amistad. De lo contrario, su relación con lo que dice apreciar se circunscribiría de manera exclusiva a la fría relación contractual, ajena al vínculo cálido al que se debe la literatura como una de las más altas expresiones del ser humano.

Y como para cada uno de nosotros el hecho mismo de existir es deseable -o casi-, así lo es también para el amigo. La existencia es deseable, sigue diciéndonos Aristóteles, porque se siente que ella es una cosa buena y esta sensación es en sí misma, insiste, dulce. Cuando se ha llegado a esa conclusión es cuando se debe consentir en que el amigo existe, lo que adviene en el convivir y el tener en común acciones y pensamientos. Acciones y pensamientos que pueden, por qué no, converger en la literatura. En este sentido se dice que los hombres convivimos, compartimos.

La amistad es, en efecto, una comunidad, y así como es con respecto a sí misma, así también lo es para el amigo. Y dado que con respecto a sí mismo, la sensación de existir en la lectura es para uno deseable, lo será también para el amigo. Es por eso por lo que uno ha sostenido desde siempre que editar es una de las posibles formas de hacer pedagogía. Desde antiguo trató ésta de despertar estados de perplejidad en los otros; estado a partir del cual se favorece la transmisión de un saber. El pedagogo es en el fondo un seductor, pues para enseñar es necesario saber inducir a los otros a amar aquello que antes aprendió a amar él.

Si profundizamos en la etimología del vocablo pedagogía, encontramos -según Corominas- que "pedagogo" (del griego pai-paidos, "niño”, y ágó, “yo conduzco") es el acompañante de niños. Hallaremos también un matiz interesante: "pedante" es una deformación cometida en la Italia del siglo XV a partir del cultismo "pedagogo" por identificación popular jocosa con la voz vulgar italiana preexistente pedante, que significa "soldado de a pie" o "peatón", aludiendo al hecho de que el acompañante de niños es peatón constante. El editor, insisto, es una suerte de pedagogo. Alguien que al conducir a otros, niños o no, se acompaña a sí mismo y no puede sino preguntarse, 
emocionarse y descubrir con ellos. Porque los caminos son múltiples y porque, aun tomando una sola senda, por más que ésta se transite una y mil veces, nunca se trata de la misma, de igual modo que la relectura de un libro nunca es la misma lectura y estamos "condenados", si ése es nuestro deseo, gozosamente a encontrarnos. Encontrémonos.

(Artículo recibido: 18-06-2010; aceptado: 26-06-2010) 